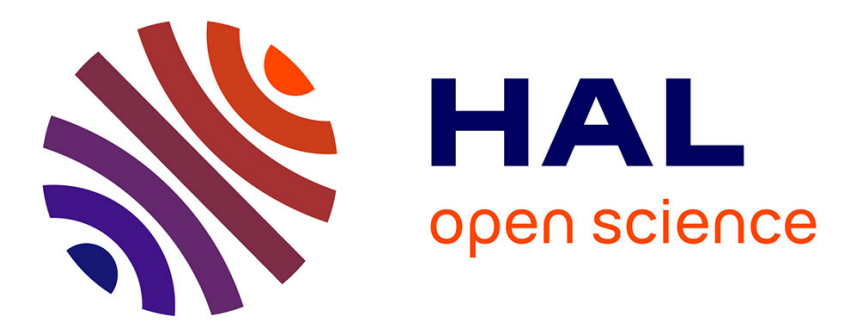

\title{
Two norms for innovation in outdoor sports: technical and social innovation
}

\author{
Pascal Duret, Katia Angué
}

\section{To cite this version:}

Pascal Duret, Katia Angué. Two norms for innovation in outdoor sports: technical and social innovation. Loisir et Société / Society and Leisure, 2015, 38 (3), pp.372-382. 10.1080/07053436.2015.1083756 . halshs-01223515

\section{HAL Id: halshs-01223515 https://shs.hal.science/halshs-01223515}

Submitted on 27 Oct 2016

HAL is a multi-disciplinary open access archive for the deposit and dissemination of scientific research documents, whether they are published or not. The documents may come from teaching and research institutions in France or abroad, or from public or private research centers.
L'archive ouverte pluridisciplinaire HAL, est destinée au dépôt et à la diffusion de documents scientifiques de niveau recherche, publiés ou non, émanant des établissements d'enseignement et de recherche français ou étrangers, des laboratoires publics ou privés. 


\title{
Two norms for innovation in outdoor sports: Technical and social innovation
}

\author{
Pascal Duret*a and Katia Angué ${ }^{\mathrm{b}}$ \\ ${ }^{a}$ Université de la Réunion, Laboratoire DIMPS, Campus universitaire du Tampon 117 rue du \\ Général Ailleret 97430, Le Tampon, France; ${ }^{b}$ MCF, Université de la Réunion, Laboratoire CEMOI, \\ Faculté de Droit et d'Economie 15, avenue René Cassin - CS 92003, 97744 Saint-Denis Cedex 9, France
}

\begin{abstract}
Technical innovation is not separated from the social so much, but it is difficult to mix the two types of innovation. It is possible to arrange innovations along a continuum where, at one pole, social innovations are conditioned by technical innovations and, at the other, social innovations are first and autonomous. Social innovations (way of living together activities), in climbing or in diving, have been conditioned by the technical innovations of safety equipment. Social innovation, in this case, is consistent with the increased use of technology. But, social innovations can be more independent from technical innovations (adventure parks do not add new technologies to the equipment used in the army, but the ways of living together are different). Users become central in social innovation in outdoor sports. Involvement of the players is an essential condition for successful innovation.
\end{abstract}

Keywords: outdoor sports; technical; technology; user

La technique n'est pas séparée du social autant, mais il est délicat d'amalgamer les deux types d'innovation. Il est possible de ranger les innovations le long d'un continuum, où à un pôle les innovations sociales sont conditionnées par les innovations techniques et à l'autre où les innovations sociales sont premières et autonomes. En escalade ou en plongée sous-marine les innovations sociales (manière de vivre ensemble l'activité) ont été conditionnées par les innovations techniques du matériel de sécurité. L'innovation sociale dans ce cas va de pair avec l'intensification du recours à la technologie. Mais les innovations sociales peuvent être plus autonomes par rapport aux innovations techniques (les parcs aventures n'ajoutent pas de nouvelles technologies aux appareillages utilisés dans l'armée, mais les manières de vivre ensemble sont différentes). Les usagers prennent une place centrale dans l'innovation sociale dans les sports de nature. L'implication des acteurs est, dans ce cadre, une condition essentielle du succès des innovations.

Mots clés : sports d'extérieur; technique; technologie; usagers

During the twentieth century and until now, natural spaces have gradually become occupied by sports activities. Initially, when sports practices meant that humans were confronted with climatic extremes (deserts, mountain peaks), they were spaces for adventure. Later, they became spaces for competition; nowadays, much has been invested in nature in terms of leisure activities, and it is for these that it is now mostly used. Innovation did not belong specifically to any one of those periods (discoveryadventure, competition, recreation); on the contrary, it was part of each of them. Such

*Corresponding author. Email: pascal.duret@univ-reunion.fr 
innovations empowered their inventors to overcome some adventure pursuit, and were subsequently used in a competitive spirit for comparing performances, and for sports in recreation activities, after they had been disseminated and mass-produced (Duret \& Trabal, 2001).

The significance of the social consequences of technical innovations in the area of outdoor sports was long minimized. Epistemologically, the overall issue of social innovation was mostly approached from the sociological perspective of organization or labor studies. In the 1980s, the main references on the subject, such as Crozier (1998) or Mintzberg (1982), construed innovation as a process of adaptation necessary for firms to survive. Innovation was opposed to routine and lack of flexibility, and thus was considered overflowing with redeeming adaptation. Those theoreticians viewed disorder as an essential resource for innovation and self-regulation. Such results, however, were applied to sports leisure activities only later. As a matter of fact, sports innovation was long viewed mostly from the perspective of performance improvement through technical transformation (Vigarello, 1988). The creation of research networks on outdoor sports (such as sportsnature.org) was a major step forward, when debates were launched on the issue of innovation in outdoor leisure activities (Corneloup \& Mao, 2010), but the debate is still quite recent.

The aim of this article is to distinguish the different patterns of links between technical and social innovations:

- Technical innovation is inseparable from intensified recourse to technology. The dérailleur in cycling, fiberglass poles in pole-vaulting, radial tires in Formula 1 and thermo-molded boot liners in Alpine skiing are examples of innovation, a word not interchangeable with invention. Technical innovation may be perceived as an invention now widely used. An invention is no more than a potential innovation, which still has to go through all the different stages - it has yet to prove that it is efficient, to be appropriated by a collective group, to meet the needs of a market, to be disseminated. In sports, the initial designer of a technical innovation is also its pioneer user. An invention is the initial artifact of a collective process (Callon \& Latour, 2002), and as Callon (1994) suggests, it is necessary to discard any 'creationist' view of innovation (Callon, 1994). Technical innovation is always a 'socio-technical' innovation. Contrary to the positivistic belief in a strong determinism which would spur innovation, there is no such thing as natural evolution or inevitable progress toward technological advancement; you must go through a series of legitimacy conflicts, involving compromise, before you can reach an agreement over what innovation is all about (Latour, 1984). Therefore, it is essential to characterize innovation as one test, not to consider it as sufficient technological progress per se for it to be adopted. In view of this, the symmetry principle suggested by Bloor (1982) is necessary to understand why an innovation was accepted or why it was rejected. Thus, some technical inventions, despite undisputable proofs of their efficiency, have remained unused, due to the social resistance that they gave rise to;

- Social innovation can be defined in the widest possible sense as an action aimed at meeting some social need by entailing strengthening of social ties; ${ }^{1}$

- For example, several authors (Charrier \& Jourdan, 1999; Duret \& Augustini, 1994; Falcoz \& Koebel, 2005; Gasparini \& Vieille-Marchiset, 2008) have shown how, in order to meet the social needs in underprivileged neighborhoods (especially to address violence), new sports systems were created. They gave new definitions 
for accessibility to sports, modes of transmission of sports knowledge and the organizing modalities for competitions, in such a framework as to foster selforganization. Such initiatives, when successful, make it possible to redefine social ties and increase solidarity, and, in that sense, are social innovation indeed. Translation sociology has shown that social innovation, just like technical innovation, results from a dynamic process of controversies supported by networks. Consquently, the innovation process ends, as Akrich (2006) suggests, when circulation of the novelty has ceased generating claims or controversies. The fact that the great majority has taken up the innovation stabilizes the way competencies are recognized in the old system and the new one. In that line of thought, social innovation implies a theory of agents in a network; what builds a 'social' group is an 'association' of agents, not their fossilized, statutory belonging to such-andsuch an organization.

Rather than listing the various levels of innovation, ranging from land development (from ski stations to parks), manufactured products (and transformation of equipment) and the new forms of sports practices (hybridization through combining innovation, such as 'kite surfing', a combination of surfing and kiting), to the forms of relations between practitioners (the change about the ties between them), we will try to focus on the social dimension of innovation, inasmuch as it produces identity disruption. Innovation about the use of sports equipment and services creates transformations in the commonly admitted characteristics and the legitimate ways of doing things in sports practices. We will identify several cases: first, when social innovation is dependent on a technical innovation (in which case it depends first on the invention of new sports materials or instruments, then on people making them their own); in the second case, technical innovation plays only a secondary role, and in the third, social innovation becomes independent from the technical component. The latter case usually consists in changes about the rules, which bring about social effects.

\section{What is successful sports innovation?}

Successful innovation is characterized by one 'invention', meeting the latent or formalized demand from a group. In fact, that is what makes the difference between successful innovation and failed innovation, which is bound to be perceived as some bizarre invention, an eccentric, useless oddity. Failed innovation is unable to find a following for itself, and above all cannot justify itself when criticized, or have an existence of its own. It may be an invention that comes too early (e.g., the back-up radar for cars, which measures the distance from an obstacle, was not selected to participate in the Lépine competition in the $1970 \mathrm{~s}$, but has been mass-produced for cars in the 2000s). An innovation is all the more fragile and vulnerable as it has no network, no group of fans; it remains an invention if it is not potentially supported by a market. As long as Steve Jobs stayed in the family garage to create personal computers, he remained a genius as an inventor; he really became an innovator only after he had founded 'Apple Inc.', with Steve Wozniak and Ronald Wayne, and managed to flood the market with Macintosh. Likewise, Petzl, a pothole explorer, was no more than an inventor as long as he was content with making the parts for his blockers and his lamps himself, in his own workshop. He became an innovator when he created a company to disseminate his lamps, not just for climbers but also for building workers. His son, P. Petzl, the current president of the company, says that his father 'for a long time worked out his ideas for his friends to 
use, making the tools which they needed to explore potholes' (Bouchet, Hillairet, \& Lewi, 2009 , p. 36). Chronologically, then, innovation comes after invention, which comes first (invention and innovation come together only in the case of manufactured products created on that concept). For Alter (2010, p. 18), 'the passage from invention to innovation is by no means immediate or linear'; the success of an innovation, according to that author, again lies in its capacity for wide dissemination.

In competitive sports, innovation enables the competitor who introduces it to pull ahead of the others. A new high jump technique, or the futuristic lines of a bike or a swimming suit, may help those who use them win a competition. As a result, the competitor who uses an innovation with a view to winning, far from wanting to disseminate it will just try to have it accepted into the current regulations of the competition. To counter the lead taken by such individuals, the history of every sport is basically 'the history of the constitution of a set of rules' (Elias \& Dunnig, 1986, p. 16), which makes it possible to preserve equality between the competitors. The evolution of sports regulations is related to the need to preserve equal chances from the start, without which it would be impossible to establish any hierarchy between the merits of each competitor at the end of the competition. Either an innovation is banned if it is not reproducible, or it is admitted if it is easily reproducible by all; this puts an end to the lead taken by the innovator, who is then bound to find new innovations (Duret \& Trabal, 2001).

The borders between technical and social innovation are so permeable that they cannot be considered as two separate areas. The technical aspect is not separate from the social one. However, the two types of innovation can hardly be amalgamated. Taking the factor for innovation as the criterion for grading, it is possible to place several models along a continuum, with social innovations conditioned by technical innovations at one end, and social innovations predominating at the other.

\section{When social innovations are conditioned by technical innovations}

Several authors have described the effects of technical innovation on sports leisure activities (Loret, 1995). In 'Génération glisse' (1995), Loret suggests that successful innovation implies several ingredients. First of all, it is necessary to create new objects (surfing and windsurfing boards, snowboards, etc.), which change the way sports people perceive their activity, and make it possible for them to shift from one culture to another (i.e., the passage from traditional competition to dissemination of the 'fun culture'). In this model, technical innovation enables cultural innovation to break forth. Technical innovations are frames of reference that foster cultural transformation. As Pociello (1995) has shown, the 'purists' in a discipline will be more reluctant about using an innovation than newcomers will. For example, in snowboarding, when traditional ski boots are discarded in favor of soft boots, it is not only free-ride techniques which are revolutionized; new forms of relations are made possible between snowboarders, who are, henceforth, freer in their movements, and less directly dependent on ski lifts.

Among the many cases which could illustrate the role of innovation in the historical evolution of sports, alpinism and climbing are most striking. A social history of alpinism cannot be separated from the evolution of the material made available to sportspeople. The attention paid to small technical objects which are easily categorized as trifles (Piette, 1996) is essential to understand the major changes in sports disciplines. For example, it is by describing how climbers have used one type of karabiner after another, or were offered new possibilities (when karabiners were made lighter, and later were fitted with new unlocking systems), that you realize how those new possibilities have influenced sportspeople's 
togetherness. In alpinism, climbing or potholing, the fact that downhillers are now acting as protectors too has changed not only individuals' relationship to safety, but the relationships between practitioners. For example, the early alpinists were physically linked to their partners by the rubbing of the S-shaped rope on their thighs, back and shoulders, so that being careful of the others also meant being directly careful for yourself. The roped party was crucial for solidarity. Roping yourself up then meant 'linking your fate to someone else's, for better and sometimes for worse; it was both a physical and a symbolical attachment' (Boutroy, 2011, p. 40). That extreme form of attachment encompasses, in the climbers' view, the need for mutual help and solidarity, interdependence in an adverse context, as well as the distribution of tasks, with a view to reaching one common objective, i.e., the summit. Once belay devices became available (such as Sticht plates in the 1970s), each climber became more autonomous; solidarity was still necessary, but one climber could be less dependent on another's speed. After they had begun using those small plates, every member of the climbing party could indulge in thinking that they no longer really needed the others, or, at any rate, that they no longer had to put their lives into other peoples' hands. The group of alpinists becomes more competitive, as members each believe they are a team by themselves, and thus are led to feel almighty. That trend was reinforced by the marketing of the ATC Guide (Air Traffic Controller) plates, which can be directly set up on a relay point so that the rope can tighten up in the event of a fall (automatic safety for the second climber in the team). Lastly, thanks to the new self-locking belay systems (of the Gri-gri, Cinch or Eddy type), it is now less vital for climbers to constantly take care of one another. As Cassirer (1944) wrote, humans are symbolic animals; as a matter of fact, the technical transformation of one real fact (through adoption of a new type of material) always carries with it an underlying symbolic dimension. When, in a climbing team, belay is no longer ensured by a human, but by pitons, the symbolism of the fall is revolutionized. Likewise, once alpinism has been superseded by free climbing in France (Aubel, 2005; De Lezeleuc, 1997), falling no longer suggests death quite so directly; it becomes part of the practice, which now includes aesthetic constraints. Sometimes, it is even thought of as a good laugh. This anecdote reported by de Leseleuc shows how what was formerly a tragedy could be turned into a joke:

The other day, I think they were both Parisians. One was a very good climber; he had been to the Claret before. The other had tried to play 'king of bongo' and failed, so he came down again.... The better one went and fixed the karabiners, then he came to the fake point and he said ... We were below, we were laughing because we didn't know he had been on that track before. The guy looked at us and said: 'Stupid you, why did you have one more piton? It was better as it was before'. Then he saw the piton (the fake one), and he said: 'Oh, fuck'. He had got it, but he said nothing. He went up, and fixed all the karabiners for his pal. His pal rushed up the track (laughs), and there he was, it was a cardboard karabiner (laughs) - cardboard, yeah??? You can imagine, Hubert could not help it; he was laughing his head off (laughs). So his pal had been in the joke all along; he had seen the fake karabiner but he said nothing'. (De Lezeleuc, 1997, p. 21)

Not all new technical devices that are introduced to increase climbers' protection and safety are necessarily accepted. Social resistance to innovation, among 'purists', is due to alleged depreciation of safety rules.

Another striking example of how technical innovations trigger off social innovation is provided by the evolution of deep-sea diving equipment. Whereas diving suits used to be linked to the boat and the pump which supplied them with air, the autonomous bottles fitted with regulators, developed by Gagnan and Cousteau in 1943, have made the equipment much lighter and more manageable in size. This has turned diving from an 
extremely risky practice into a leisure one. Deep-sea divers were people with extraordinary courage, daredevils whose love for the seabed could not reasonably be taken up as a model reproducible for ordinary people. Unlike them, divers who use bottles (patented and trademarked 'aqualungs' by Cousteau in 1945) can be viewed as leisure figures. The successive generations of regulators (Mistral, Spiro \& Neuchat), as well as stabilizing jackets, are making diving increasingly accessible. The diving team is a metaphor for solidarity between divers as well as solidarity between them and nature. Here is the same figural contrast between an individual who is isolated, though dependent on others (the deep-sea diver who is alone in the depth of the sea but is kept alive by the 'umbilical cord' which links him to the air pump on the boat), and the group, which is convivial precisely because of the solidarity among all the members (the deep-sea divers), though they are not dependent on one another. No wonder the 'Club Méditerranée' made diving one of its key activities in the 1970s; the idea was to discover the seabed in a merry, recreational way, thanks to technical progress.

One more example of the social effects of a technical innovation is provided by the shift from the traditional mountain bike to the double suspension, and later the 'free-ride' (wholly suspended) bikes. That technical innovation transformed the practice, which from a predominantly energy sport became a gliding one, in which balance and sensations are the primary aim. Thanks to increased clearance of the fork, shocks are better absorbed, leaving the mountain bikers free to ride on steeper, more jolting tracks. But the idea, rather than the ability to toil up the steepest lanes, is now to race down the steepest slopes. Sportspeople are younger, as the evolution of the ages among the members of the federation shows.

\section{When social innovation prevails}

A second comprehensive type of innovation is social innovations which do not directly depend on technical innovations, but address a social issue. For instance, 'shark alert' security systems were established by surfers on Reunion Island after an outbreak of shark attacks. Since 2011, due to more frequent shark attacks, beaches have been gradually closed off, and access to the waves ('spots') forbidden. To make up for a lack of public management of the shark risk, other than bluntly creating a ban on surfing, sportspeople concerned with the risk, and those in charge of raising the alarm, organized themselves with a view to ensuring safe practice of the sport. The system they established is a sports innovation as the surfers, to ensure their own safety, gave up a traditional practice (wave riding) by 'taking over' the stream below the waves. Here is division of labor, with one surfer on the board being accompanied by another who is swimming without an aqualung below the water to prevent a possible shark attack. New physical dimensions (getting familiar with the environment underwater, diving without an aqualung) as well as symbolic ones (immersion increases the symbolic presence of the risk) are added to the ordinary practice of surfing. This is social innovation inasmuch as the adjustment entails a new distribution of tasks, or even a covenant with divers. Here is indeed 'unexpected association' (Alter, 2010, p. 73). For a social innovation to be understood, it must be framed in its social context - in this case, the context of the 'shark crisis' (Thiann-Bo \& Duret, 2013) - so that the constraints it has taken into account and the normative system from which it originated, or against which it was deployed, can be identified. The new way of surfing in pairs (a surfer/an underwater watchman) has emerged in a political context characterized by contrasted, competing stances ranging from denial and blurring out the risk to over-dramatizing and exaggerating it. One major consequence of that wide 
gap between the different policy stances is that it leads to inaction on the part of decision makers. Surfers are all the more at liberty to innovate as they can use the space that public management of the shark risk has left vacant. They have positioned themselves by opposing the institutions (the marine reserve, scientific research organizations), which they describe as impotent in addressing the crisis. They even consider that such institutions are the sources of the attacks, as the conservation of fish species has created an attractive food reserve for the increasing population of sharks. They are seeking to innovate as far as they can, considering that the risk taking involves only their responsibility as surfers.

The overall creative process is usually the result of several factors or entities combining to usher in the shift from one configuration to another (Hillairet, 2005). A field survey by Thiann-bo (observation of three shark-alert systems, monitoring and interviewing 23 surfers, monitoring the Facebook virtual community) led to a better understanding of the surfers' reasons for innovating (Thiann-Bo \& Duret, 2013). Not all sports people have the same reasons for innovating. Some advocate enhanced responsibility and sustainable change among individual surfers. Others have set up an association to gain influence over the public management of the risk, and believe that the present shark-alert systems should be no more than an 'additional' remedy within a larger safety system (intensive shark fishing, frightening the sharks off). The systems they imagine also depend on their own relationship to nature and to the animals. The reasons for innovating vary depending on the animal mythologies mentioned by the surfers. The more harmful sharks are perceived to be, the more superfluous, or even irrelevant, the question of respecting them becomes.

As it turns out, the following were the characteristics necessary for that social innovation: the lack of public policies, rising awareness among the various users of the ocean (with some usually identifying themselves by rejecting the others) and the building of solidarity. The surfers ask people from other water disciplines, during a competition for instance, to help them make their surfing sites safe. For as long as one session lasts, the shark-alert people stop being surfers; they become 'watchmen' in charge of keeping watch on sharks underwater. There are different types of shark-alert people - on a boat, underwater or on land (the latter are also known as 'shark spotters'). The shark-alert system is an innovation in usage, which consists in engaging individual surfers in more activities: during a session, they become divers, swimmers and surfers in turn. They get organized in an autonomous way, broadcasting the best weather conditions for practice and setting up groups with enough members to ensure safe surfing. Steps are taken to make the exchange of positions possible. In this model, the social innovation is supported by technological innovations, such as Smartphone apps to build synergy between the actors.

\section{When social innovations become independent from technical ones}

Some social innovations do not need any technical support at all to develop, and are, therefore, of the solely social type. For example, one activity may simply move from one public to another. For instance, the paths in adventure parks are more or less those laid out by commando training centers (particularly the Montlouis Center). The equipment for military training (Tyroleans, pendulums, rope bridges, etc.) was not technically improved when it was imported into adventure and leisure sites; the innovation concerns solely the change of public and the way physical testing is conducted. Whereas in commando training centers, instructors usually get the trainees to work the rough way, adventure site coordinators tell tourists: 'You go ahead when you like, when you feel like it'. The 
obstacle will be overcome in both cases, but whereas in the former it is under duress, in the latter the decision to start the action is left to the user.

A good example of this type of social innovation is provided by raids and extreme races such as sand marathons or the Réunion Grand Raid, in which the social changes are derived solely from innovations about the rules. The latter do not conform to the 'creative destruction' process which Schumpeter (1934) described in the early twentieth century. New modalities are simply superposed on old ones, which are not erased. There is no revolution in the norms, just the coexistence of several norms. In addition, the innovation is recognized as such by the participants. One essential effect of the innovation in such races is that individuals are free to define the type of relationship they want to have with the others. The racers fashion their races as they like. The races are innovative in that they leave the participants free to choose between different values - competition, discovery and care for others. Here is a model of sports in which competition for the best ranking coexists with good-humored shunning of any 'win at all costs' spirit. It has done away with the seemingly irreconcilable rift between ruthless sport clashes and leisure-discovery activities. In this case, it is up to everyone to choose their own mix of both trends. Everyone is free to shape their own conception of the race, and eventually their conception of themselves. These are infinitely variable exercises which, far from submitting to inflexible prescriptions of uniform types of conduct, authorize or even encourage participants to engage in a wide range of personal projects. Downright competition has not been swept away by new forms of softer, convivial competition. The old modalities have not been declared obsolete to make room for new ones. In fact, the innovation lies precisely in tolerant coexistence of the old and the new. The social innovation lies in turning away from uniform projects and behaviors. That tolerance to diversity is what cements unity among the racers. Participants do not claim they belong to any particular community or sports fraternity (which would imply indissoluble ties), but rather welcome strangers benevolently. Coming to participate in the 'Grand Raid' or other trails does not make participants 'brothers' or members of one family. Each participant comes in a private capacity. Relationships during a race are all the more intense as, paradoxically, they do not involve any lasting community. The ties are more friendly (Tonnies call them 'members') than brotherly ('community'). Relationships between sportspeople have usually been glorified, especially by the thinkers who started the sports movement, as brotherly which implies continuity of a kind (you cannot say: 'You're no longer my brother', whereas you can say: 'You're no longer my friend'). Sports brotherhood is historically based on patriotic values which exalt common belonging (whether to a town, a region or a nation). On the contrary, friendship implies an elective choice of 'individualized individuals' (Singly, 2003), tracing an ideal tie based on liberty and conviviality. The project consists in giving up all ideas of uniform commitments and conducts. This is akin to the stance taken by Julia Kristeva (1988), who claimed that the world should be viewed as entirely made up of strangers. If everyone is a stranger to the others, then nobody is, since if there is no identity to which you belong, then there is no possibility to discriminate otherness. The cost for that type of association is that the ties are very short-lived. This form of raid is all the more socially innovative as those new forms of ties between 'strangers' who did not know one another before the race began are superposed on traditional, long-standing sports friendship.

The identity disruption suggested by that type of race implies the emergence of a 'we' - not a 'multiplied I' (in which each competitor has the same project as their neighbor), but a 'dilated I' (in which the identity profile of the race is provided by the sum of the various projects of the competitors). In the former case, that of traditional marathons, 'we' 
is based on a single project; in the latter, that of the Réunion Grand Raid, everyone may join in with their own project. Such emancipation from a single project implies that everyone accepts and more or less identifies with their neighbor's project, even though it is not their own; in that collective identity scheme, individuals may find themselves outside themselves. That type of race is a metaphor for common humanity. The shift from 'me' to 'us' does not necessarily mean that the image which individuals have of their own activity is strengthened; rather, it is a way of accepting through 'us' some sports modalities which are different from our own. Individuals thus assert themselves in the human condition, by simultaneously claiming their right to be different, a multicultural sports event and inseparably, their own individuation. The group, far from making the participants uniformly similar, enables them to hold a position which provides their subjectivity with visibility. The idea is to think of others as both different and equal, an innovation as far as social ties are concerned. For the thinkers of the right to be different, such as Louis Dumont, the only way to escape the relativism of an 'equal status' society or group is to establish hierarchy. Consequently, in the view of the author of Homo hierarchicus and Essais sur l'individualisme, the only way otherness can be recognized is by conferring on it a value lower or higher than the one you confer on yourself. Louis Dumont (1983) is adamant that 'only hierarchy can ensure recognition; I maintain that when the advocates of difference claim both for equality and recognition, they are claiming for the impossible' (1983, p. 260).

\section{Conclusion}

In the case of technical innovation, a small group of innovators, or even a single person, initially tries to address an individual issue, whereas, from the start, a social innovation is intended to address a social issue. Reality concerning the process of technical innovation certainly belies the myth of the 'genius handyman' who would also turn out to be a genius entrepreneur as well as a genius communicator and a genius negotiator... It is not so easy to be outstandingly good in every area (and even if that were true, it would still be very difficult to move from one area to another); that is the reason inventors need specific allies if they are to control at least part of the innovation process. As a result, in the realm of innovation, sociologists are usually faced with the hen/egg paradox. Is successful innovation related to the characteristics of the product, or rather to the properties of the receiving market (Mendras \& Forsé, 1997)? To overcome the dilemma, translation sociologists cancel out the terms of the alternative: in their view, the social environment is built simultaneously with the innovation it will assess (Akrich, Callon, \& Latour, 2006). Consequently, it is necessary to envisage joint building of the innovation and of the attendant social order.

Users hold a central position in social innovation as far as outdoor sports are concerned. Representation of sportspeople by proxy (through experts, elected representatives or managers) can hardly be enough for this type of innovation. In such a framework, involvement of the players is an essential condition for successful innovation. It is the users themselves who make the devices their own, transforming and stabilizing them in the process. The userinnovator will find ways of pushing back the limits of devices. It thus appears that in outdoor sports, the division of labor between those who design the innovation and those who are supposed just to use it is sometimes far from distinguishable.

Social innovation in outdoor sports nowadays consists in refraining from defining $a$ priori a single legitimate form of social ties; far from that, it consists in enabling a variety of norms to come out. In addition, it offers a compromise between individuals' claims for 
ever-increasing autonomy and their wish for continued relationship with their friends. Social innovation in outdoor sports makes it possible for individuals both to assert themselves as such and to meet the expectations of collective living.

\section{Disclosure statement}

No potential conflict of interest was reported by the authors.

\section{Note}

1. Theoretically, the will to delete the tie could also be an object for innovation, but actually it is cohesion and reinforcement of the tie which are aimed at through the facilities intended for social innovation.

\section{References}

Akrich, M. (2006). Les objets techniques et leur utilisateur : de la conception à l'action. Dans M. Akrich et B. Latour (dirs.), Sociologie de la traduction. Textes fondateurs. Paris : Presses de l'Ecole des Mines, Sciences sociales (Coll.).

Akrich, M., Callon, M., et Latour, B. (2006). Sociologie de la traduction. Textes fondateurs. Paris : Presses de l'École des Mines, Sciences sociales (Coll.).

Alter, N. (2010). L'innovation ordinaire. Paris : Presses universitaires de France.

Aubel, O. (2005). L'escalade libre en France. Paris : L'Harmattan.

Bloor, D., (1982). Durkheim and Mauss revisited: Classification and the sociology of knowledge. Studies in the History and Philosophy of Sciences, 13, 267-297.

Bouchet, P., Hillairet, D., \& Lewi, G. (2009). Marques du sport. Bruxelles : De Boeck.

Boutroy, E. (2011). L'esprit de cordée. Dans Duret (dir.), Faire Equipe. Paris : Armand Colin.

Callon, M. (1994, mars). L'innovation technologique et ses mythes. Gérer et comprendre, 34, 5-17.

Callon, M., et Latour, B. (2002). L'innovation, un processus collectif ambigu. Dans N. Alter (dir.), Les logiques de l'innovation. Paris: La découverte.

Cassirer, E. (1944). An essay on man: An introduction to the philosophy of human culture. New Haven, CT: Yale University Press.

Charrier, D., et Jourdan, J. (1999). Insertion par le sport : le choc des cultures. Sport, Europe, Stratégies. Revue europeenne de management du sport, 20, 20-39.

Corneloup, J., et Mao, P. (2010). Créativité et innovation dans les loisirs sportifs de nature. L'argentière : Le Fournel.

Crozier, M. (1998). À propos de l'innovation. Éducation permanente, 134, 14-31.

De Lezeleuc, E. (1997). Comment peut-on enseigner une culture corporelle? Tréma, hors serie 1, $17-25$.

Dumont, L. (1983). Essais sur l'individualisme. Paris : Le Seuil.

Duret, P., et Augustini, M. (1994). Sports de rue et insertion sociale. Paris : INSEP.

Duret, P., et Trabal, P. (2001). Le sport et ses affaires, Une sociologie de la justice de l'épreuve sportive. Paris : Métailié.

Elias, N., et Dunnig, E. (1986). Sport et civilisation. La violence maitrisée. Paris : Fayard.

Falcoz, M., et Koebel, M. (dirs.). (2005). Intégration par le sport : representations et réalités. Paris : L'Harmattan.

Gasparini, W., et Vieille-Marchiset, G. (2008). Le sport dans les quartiers : pratiques sociales et politiques publiques. Paris : Presses universitaires de France.

Kristeva, J. (1988). Étrangers à nous-mêmes. Paris : Fayard.

Latour, B., (1984). Les microbes : guerre et paix. Paris : Métailié.

Loret, A., (1995). Géneration glisse : dans l'eau, l'air, la neige ... la révolution du sport des "années fun". Paris : Autrement.

Mendras, H., et Forsé, M. (1997). Le changement social. Paris : la Découverte.

Mintzberg, H. (1982). Structures et dynamiques des organisations. Paris : Eyrolles.

Piette, A. (1996). Ethnographie de l'action. Paris : Métailié.

Pociello, C. (1995). Les cultures sportives. Paris : Presses universitaires de France. 
Schumpeter, J. (1934). The theory of economic development. Cambridge, MA: Harvard University Press.

Singly, F. (de) (2003). Les uns avec les autres, quand l'individualisme crée du lien. Paris : Armand Colin.

Thiann-Bo Morel, M., Duret, P., (2013). Le risque requin, mise en risque de la pratique du surf à la Réunion. revue STAPS, 99, pp. 23-36.

Vigarello, G. (1988). Techniques d'hier et d'aujourd'hui. Paris : Revue EPS/Laffont. 